UDK 528.481:551.24

\title{
DABARTINIŲ GEODINAMINIŲ PROCESŲ TYRIMAS ŠIAURĖS RYTINĖJE LIETUVOS DALYJE
}

\author{
Algimantas Zakarevičius, Asta Anikẻnienė \\ Geodezijos ir kadastro katedra, Vilniaus Gedimino technikos universitetas, \\ Sauletekio al. 11, LT-10223 Vilnius, Lietuva \\ El.paštas: gkk@ap.vgtu.lt
}

Iteikta 200602 12, priimta 20060330

\begin{abstract}
Santrauka. Lietuvos vertikaliojo geodezinio tinklo poligone Vilnius - Jonava - Zarasai - Turmantas - Vilnius pagal geodezinių matavimų rezultatus atlikta nustatytų dabartinių vertikaliụjų Žemès plutos judesių greičių statistinẻ analizè.

Darbo tikslas - remiantis naujausių geodezinių matavimų duomenimis nustatyti dabartinių Žemès plutos judesių intensyvumą šiame regione ir jų kitimą einant laikui.

Pagal 1934, 1935-1936, 1948, 1968, 1970, 1980, 1985-1987, 1998, 2005, 2006 metu niveliaciju matavimo rezultatus nustatyta, kad poligone Vilnius - Jonava - Zarasai - Turmantas - Vilnius dabartinių vertikaliujų Žemès plutos judesių greičiu amplitudè siekia iki 5-6 mm/metus. Atliekant matavimo rezultatu matematinę statistinę analizę, su $95 \%$ tikimybe pagrịsta, kad Žemès plutos judesiai bẻgant laikui yra svyruojamojo pobūdžio. Per pastarujuc 25 metų laikotarpi Zarasu - Turmanto linija Vilniaus - Jonavos atžvilgiu kyla iki 4-6 mm per metus greičiu. Tokio intensyvumo geodinaminius procesus būtina ịvertinti atliekant tiksliąsias niveliacijas.
\end{abstract}

Reikšminiai žodžiai: vertikalieji Žemès plutos judesiai, regresinis modelis.

\section{Ivadas}

Dabartiniu geodinaminių procesu tyrimas yra svarbi ne tik moksline, bet ir praktinè problema, susijusi su geodezinių tinklų sudarymu bei naudojimu [1, 2]. Šie tyrimai yra vieni iš prioritetinių Žemès mokslų srityje ir atliekami seismiškai aktyvioms teritorijoms bei juc pavojingumo laipsniui nustatyti [3, 4].

Norint ivertinti dabartinius geodinaminius procesus sudarant ir eksploatuojant geodezinius tinklus, prognozuojant teritorijų seisminị pavojingumą bei sprendžiant kitus mokslinius ir praktinius uždavinius, reikia žinoti Žemès plutos judesių savybes ir jų kaitą. Vienas svarbių klausimu yra nustatyti, ar judesių intensyvumas bei kryptis einant laikui yra pastovi, ar kinta. Apie Žemès plutos judesių savybių kaitą laikui bėgant yra nemažai duomenų ir hipotezių $[1,2,5,6]$. Konstatuoti ne tik greičiu pokyčiai, bet ir judesių krypties inversijos, tačiau ne visi šie rezultatai pakankamai pagrịsti matavimais. Dažnai šioms išvadoms pagrịsti nepakakdavo kartotinių matavimų arba nepakankamas būdavo matavimu tikslumas.

Šio darbo tikslas - remiantis naujausių tiksliuju niveliacijų matavimų duomenimis Šiaurès Rytų Lietuvos teritorijos pavyzdžiu ištirti dabartinių vertikaliujų Žemès plutos judesių savybes ir teritorinę sklaidą bei kaitą laikui bègant.

Lietuvos Šiaurès Rytų regionas pasirinktas iš ankstesnių tyrimų žinant, kad šioje teritorijoje vyksta gana intensyvūs geodinaminiai procesai, konstatuotos Žemès plutos judesių krypties inversijos einant laikui [1,
2, 5]. Šios inversijos kèlè nemažai mokslinio pobūdžio klausimų, tačiau i juos nebuvo pagristai atsakyta dèl patikimu matavimu stokos. Prielaidos apie judesių inversiją padarytos remiantis ir dvidešimtojo šimtmečio pradžios niveliacijomis, kurios nebuvo labai tikslios, bei nedideliu pakartotinai niveliuotų ženklų skaičiumi. Kad tam tikrose Rytu Lietuvos teritorijose pasireiškia Žemès plutos judesių ne tik greičiu kaita, bet ir inversijos, nustatyta atliekant tyrimus Ignalinos atominès elektrinès geodinaminiame poligone $[2,7,8]$ bei netoliese esančiame Baltarusijos geodinaminiame poligone [9].

Tyrimams naudota 1934-2006 m. laikotarpiu atliktos tiksliosios niveliacijos duomenys.

Darbo mokslinis naujumas - patikslintos dabartiniu vertikaliujų Žemès plutos judesių charakteristikos Šiaurès Rytu Lietuvos regione bei statistiškai patikimai irodyta judesiu greičiu kaita ir judesių krypties inversijos einant laikui.

Autoriai dèkoja Vilniaus Gedimino technikos universiteto Geodezijos mokslo institutui už suteiktą galimybę atliekant mokslinius tyrimus pasinaudoti sudaromo Lietuvos vertikaliojo geodezinio tinklo matavimų duomenimis.

\section{Tyrimų metodika}

Vertikaliesiems Žemès plutos judesiams Šiaurès Rytu Lietuvos dalyje nustatyti remtasi poligone Vilnius Jonava - Zarasai - Turmantas - Vilnius 1934-2006 m. laikotarpiu atliktos tiksliosios niveliacijos duomenimis. 
Vertikaliuju judesių greičiams apskaičiuoti taikomi tiesiogiai tarp gretimų geodezinių ženklų išmatuoti aukščiu skirtumai. Tuomet reliatyvusis vieno geodezinio ženklo vertikaliojo judesio greitis kito geodezinio ženklo atžvilgiu yra

$$
v_{i j}=\frac{h_{i j}^{\prime \prime}-h_{i j}^{\prime}}{t},
$$

čia $h_{i j}^{\prime}, h_{i j}^{\prime \prime}$ - pirmojo ir antrojo matavimų metu išmatuoti aukščiu skirtumai tarp geodezinių ženklų $i$ ir $j, t-$ laiko tarpas tarp kartotinių matavimu.

Geodezinių ženklų niveliavimo trasoje vertikaliuju judesių reliatyvieji greičiai pradinio trasos taško atžvilgiu apskaičiuojami kaip gretimų reperių vertikaliuju judesių vienas kito atžvilgiu greičių kumuliacinès sumos:

$$
v_{k}=\sum_{i=1}^{k} v_{i-1, i}
$$

čia $i=0,1, \ldots, k$ - geodezinių ženklų niveliacijos eigoje numeriai.

Išmatuotieji vertikalieji geodezinių ženklų poslinkiai bei ju greičiai, sutapatinami su Žemès plutos vertikaliaisiais poslinkiais ir poslinkių greičiais, yra tektoninès ir netektoninès kilmès judesių, kylančių dèl ivvairių gamtinių bei antropogeninių priežasčių, algebrine suma. Šioms lokalioms atsitiktinių priežasčių lemiamoms anomalijoms eliminuoti ir dèsningajam trendui nustatyti bei patikrinti jo adekvatumui matavimo rezultatams taikomi matematiniai statistiniai matavimuc rezultatuc analizès metodai [10].

Vienas iš tokių metodų, gerai tinkantis nagrinejjant Žemès plutos judesių dèsningumus pagal niveliacijos linijas, yra regresinè analizè. Darbe taikytas daugianaris regresijos modelis:

$$
v_{i}=\beta_{0}+\beta_{1} S_{i}+\beta_{2} S_{i}^{2}+\beta_{3} S_{i}^{3}+\ldots+\beta_{m} S_{i}^{m},
$$

$v_{i}-i$-tojo geodezinio ženklo vertikaliojo judesio, aprašyto regresiniu modeliu, greitis, $\beta_{i}(i=0,1,2, \ldots, m)-$ regresinio modelio parametrai, $S_{i}-i$-tojo geodezinio ženklo atstumas nuo linijos pradžios.

Kai $m=1$, gaunamas linijinis regresinis modelis.

Matricine forma galima parašyti

$$
V=\beta X,
$$

čia

$$
\begin{aligned}
& V=\left(v_{1} v_{2} \ldots v_{n}\right)^{T}, \\
& \beta=\left(\beta_{0} \beta_{1} \beta_{2} . . \beta_{m}\right)^{T},
\end{aligned}
$$

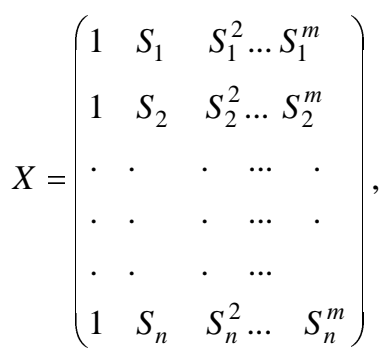

$m$ - daugianario modelio eilè (laipsnis), $n$ - geodeziniu ženklų nagrinèjamoje trasoje skaičius.

Tariant, kad matavimai vienodo tikslumo, mažiausiujų kvadratų metodu įvertinti regresinio modelio lygties koeficientai:

$$
\hat{\beta}=\left(X^{T} X\right)^{-1} X^{T} V
$$

Vertinant sudaryto regresinio modelio adekvatumą nagrinėjamoje trasoje išmatuotiems vertikaliujų Žemès plutos judesių greičiams skaičiuojama $F$ statistika

$$
F=\frac{\left(\hat{\beta} X^{T}-n \bar{v}^{2}\right)(n-m-2)}{\left(X^{T} X-\hat{\beta} X^{T} V\right)(m-1)},
$$

čia $\bar{v}$ - vidutinè priklausomojo kintamojo (Žemès paviršiaus vertikaliujų judesių greičių) reikšmė nagrinèjamoje linijoje, $n$ - geodezinių ženklų (išmatuotų judesių greičiu) skaičius, $m$ - daugianario laipsnis.

Statistika $F$ turi $k_{1}=m-1 \quad$ ir $\quad k_{2}=n-m-2$ laisvès laipsnius. Jeigu $F>F_{q\left(k_{1}, k_{2}\right)}$, tai su tikimybe $p=1-q$ galima teigti, kad reikšmès, gautos taikant regresini modelį, yra adekvačios išmatuotų vertikaliujų Žemès paviršiaus judesių reikšmėms, t. y. regresiniu modeliu aprašytų Žemès plutos judesių trendas adekvatus matavimais nustatytam tikrajam fiziniam procesui. Jeigu $F<F_{q\left(k_{1}, k_{2}\right)}$, tai su tikimybe $p=1-q$ galima teigti, kad regresinis modelis neatitinka tikrojo judesių modelio, t. y. jis neadekvačiai atspindi vykstančius tikruosius Žemès paviršiaus judesius ir yra netaikytinas.

Regresijos modelio sąsajoms su tikruoju fiziniu procesu ivertinti skaičiuojamas determinacijos koeficientas:

$$
R^{2}=\frac{\hat{\beta}^{T} X^{T} \hat{V}-n \bar{v}^{2}}{V^{T} V-n \bar{v}^{2}},
$$

$V, \hat{V}$ - išmatuotu ir pagal regresini modeli apskaičiuotuc vertikaliujų judesių greičių vektoriai. Nustatytu vertikaliuju judesių greičių sklaidos dalis įvertinama pagal regresinį modeli.

Regresijos lygties koeficientų dispersijų įverčiai

$$
\sigma^{2}\left(\beta_{i}\right)=\sigma^{2} K_{i i}
$$




$$
\begin{aligned}
& \sigma^{2}=\frac{\sum_{i=1}^{n}\left(v_{i}-\bar{v}_{i}\right)^{2}}{n-m-1}, \\
& K_{i i}-(i=0,1,1, \ldots, n) \text { matricos } \\
& K=\left(X^{T} X\right)^{-1}
\end{aligned}
$$

diagonalieji elementai, $m$ - daugianario laipsnis.

Regresinès lygties parametru pasikliautinieji intervalai su tikimybe $p=1-q$ yra

$$
P\left[\begin{array}{l}
\left(\hat{\beta}_{i}-t_{\frac{q}{2} ; n-m-1} \sigma\left(\beta_{i}\right) \leq \beta_{i} \leq \hat{\beta}_{i}\right. \\
\left.+t_{\frac{q}{2} ; n-m-1} \sigma\left(\beta_{i}\right)\right)
\end{array}\right]=1-q .
$$

Koeficientas $t_{\frac{q}{2} ; n-m-1}$ gaunamas iš $t$ skirsnio [10].

Regresinès funkcijos pasikliautinasis intervalas su tikimybe $p=1-q$ yra

$$
\begin{aligned}
& P\left[\begin{array}{l}
\bar{v}_{i}-t_{\frac{q}{2} ; n-m-1} \cdot \sigma \sqrt{1+\bar{X}_{i}^{T}\left(X^{T} X\right)^{-1} \bar{X}_{i}} \leq \\
v_{i} \leq \bar{v}_{i}+t_{\frac{q}{2} ; n-m-1} \cdot \sigma \sqrt{1+\bar{X}_{i}^{T}\left(X^{T} X\right)^{-1} \bar{X}_{i}}
\end{array}\right]= \\
& 1-q,
\end{aligned}
$$

čia

$$
\bar{X}_{i}=\left(\begin{array}{llll}
1 & S_{i} & S_{i}^{2} & \ldots S_{i}^{m}
\end{array}\right)^{T} .
$$

Regresinio modelio greičiu gradientas yra regresinès lygties išvestine pagal kintamaji $\varsigma$. Tiesinio regresinio modelio atveju

$$
\operatorname{grad}(v)=\beta_{1}
$$

Tarpusavyje palyginamų regresinių modelių greičių gradientų skirtumas

$$
\Delta=\operatorname{grad}(v)^{\prime}-\operatorname{grad}(v)^{\prime \prime}=\beta_{1}^{\prime}-\beta_{1}^{\prime \prime},
$$

čia $\beta_{1}^{\prime}$ ir $\beta_{1}^{\prime \prime}$ - tarpusavyje palyginamu regresiniu modeliu koeficientai.

Gradientų standartiniai nuokrypiai yra lygūs regresijos koeficiento $\beta_{1}$ standartiniam nuokrypiui, t. y. $\sigma(\operatorname{grad} v)=\sigma\left(\beta_{1}\right)$.

Tuomet skirtumo $\Delta$ dispersija ịvertinima:

$$
\sigma^{2}(\Delta)=\sigma^{2}\left(\beta_{1}^{\prime}\right)+\sigma^{2}\left(\beta_{1}^{\prime \prime}\right)
$$

Statistikos $t$ iqvertis

$$
t=\frac{\Delta}{\sigma(\Delta)}
$$

Kai $t>t_{q, k}$ su tikimybe $p=1-q$ galima teigti, kad greičių gradientų skirtumai statistiškai reikšmingi. Šiuo atveju su ta pačia tikimybe galima teigti, kad lyginamaisiais laikotarpiais greičių gradientu reikšmès pakito. Čia $t_{q, k}-t$ statistikos teorinè reikšmé esant patikimumo $q$ ir $k=\left(n_{1}-2\right)+\left(n_{2}-2\right), \quad n_{1}, \quad n_{2}-$ pakartotinai niveliuotų geodezinių ženklų, panaudotų sudarant regresinius modelius, skaičius.

\section{Tyrimų rezultatai}

Vertikaliuju Žemès plutos judesių šiaurès rytinejje Lietuvos dalyje savybems nustatyti remtasi kartotiniu niveliacijų poligone Vilnius - Jonava - Zarasai Turmantas - Vilnius 1935-2006 m. laikotarpiu atliktu tiksliujų niveliacijų duomenimis.

Jonavos - Zarasu linijos preciziné niveliacija daryta:

- 1935-1936 m. - atliko Lietuvos krašto apsaugos ministerija; matavimų tikslumas - 0,27 mm/km [11];

- 1980 m. - atliko Vyriausiosios geodezijos ir kartografijos valdybos 5-oji imoné; matavimų tikslumas $0,62 \mathrm{~mm} / \mathrm{km}[12]$

- 2005 m. - atliko VGTU Geodezijos institutas; matavimu tikslumas $-0,38 \mathrm{~mm} / \mathrm{km}$ [13];

Turmanto - Vilniaus linijos:

- 1948 m. - atliko Vyriausioji geodezijos ir kartografijos valdyba; matavimų tikslumas - 0,98 $\mathrm{mm} / \mathrm{km}$ [14];

- 1968 m. - atliko Vyriausiosios geodezijos ir karografijos valdybos 7-oji imoné; matavimų tikslumas $0,68 \mathrm{~mm} / \mathrm{km}[12]$;

- $\quad$ 1985-1987 m. - atliko Vyriausiosios geodezijos ir kartografijos valdybos 5-oji imonè; matavimu tikslumas - 0,69 mm/km [12];

- 2005-2006 m. - atliko VGTU Geodezijos institutas; matavimų tikslumas - 0,34 mm/km [15];

Vilniaus - Jonavos linijos:

- 1934 m. - atliko Lietuvos krašto apsaugos ministerija; matavimų tikslumas - 0,27 mm/km [11];

- 1948 m. - atliko Vyriausioji geodezijos ir kartografijos valdyba; matavimu tikslumas - $0,60 \mathrm{~mm} / \mathrm{km}$ [14];

- $\quad$ 1970-1971 m. - atliko Vyriausiosios geodezijos ir kartografijos valdybos 7-oji imone; matavimu tikslumas $-0,53 \mathrm{~mm} / \mathrm{km} \mathrm{[12]}$;

- 1998 m. - atliko VGTU Geodezijos institutas; matavimu tikslumas $-0,36 \mathrm{~mm} / \mathrm{km}$ [16];

Poligono liniju skirtingu laiko tarpų matavimo rezultatų analizè atlikta pagal pateiktą metodiką.

Vertikaliuju Žemès plutos judesių pirmosios ir antrosios eilès regresiniai modeliai (3), jų patikimumą ir adekvatumą matavimų rezultatams apibūdinantys rodikliai (9) bei (10) pateikti 1 lenteleje. 
Iš 1 lentelès duomenų matyti, kad taikant tiesini bei pirmosios eilès daugianarị regresini modeli Šiaurès Rytu Lietuvos teritorijoje pakankamai adekvačiai (su tikimybe $p \geq 0,95)$ bendruosius vertikaliujų judesių greičius atspindi pirmosios eilès (tiesiniai) modeliai. Nagrinéjamose linijose $F>F_{q\left(k_{1}, k_{2}\right)}$, taigi su tikimybe $p=1-q \geq 0,95$ galima teigti, kad reikšmès, gautos taikant tiesinį regresinị modelị, yra adekvačios išmatuotu vertikaliujų Žemès paviršiaus judesių reikšmėms.

Niveliacijos liniju matavimu rezultatai, tiesiniai regresijos modeliai (3) ir jų pasikliautinieji intervalai (15) su tikimybemis $p=0,95$ ir $p=0,99$ būdingiausiais skirtingu vertikaliujų judesių savybių laikotarpiais grafiškai atvaizduoti $1-6$ paveiksluose.

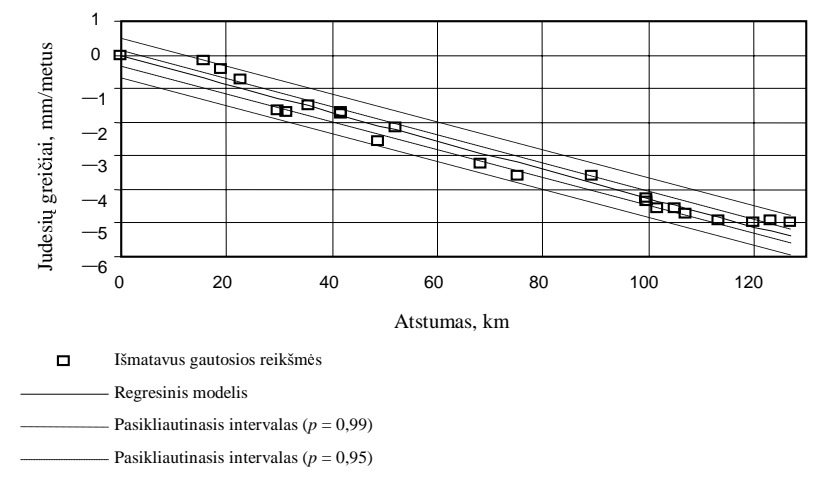

1 pav. Žemès paviršiaus judesiai 2005-2006 - 1985-1987 m. Turmanto - Vilniaus linijoje (tiesinis modelis)

Fig 1. Earth surface movements (2005-2006 - 1985-1987) in line Turmantas - Vilnius (linear model)

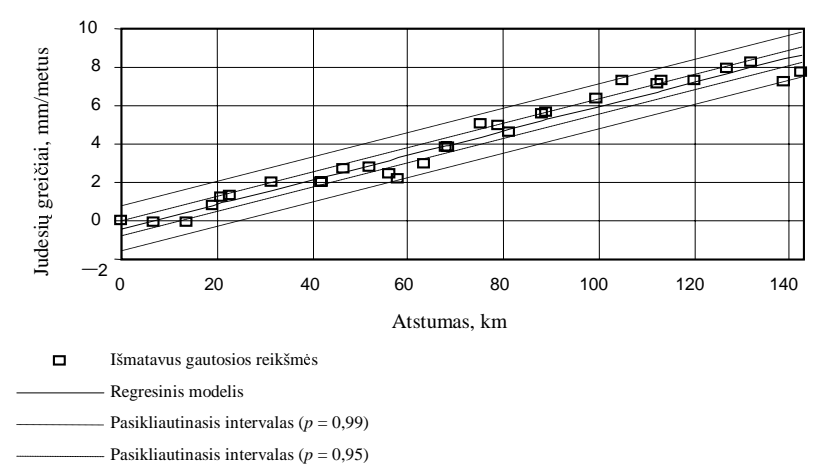

2 pav. Žemès paviršiaus judesiai 1985-1968 m. Turmanto Vilniaus linijoje (tiesinis modelis)

Fig 2. Earth surface movements (1985-1968) in line Turmantas - Vilnius (linear model)

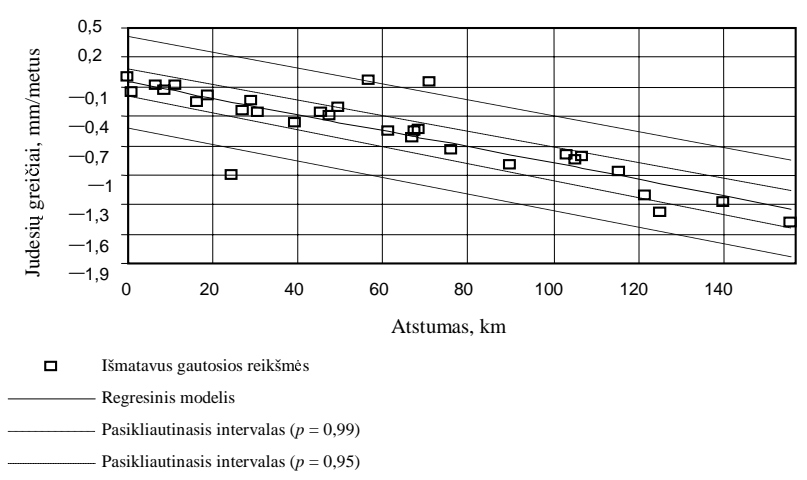

3 pav. Žemès paviršiaus judesiai 1980-1935-1936 m. JonavosZarasu - Turmanto linijoje (tiesinis modelis)

Fig 3. Earth surface movements (1980-1935-1936) in line Jonava - Zarasai - Turmantas (linear model)

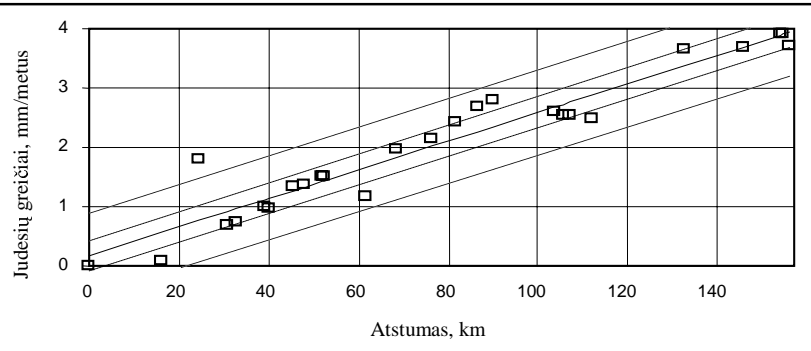

ㅁ Išmatavus gautosios reikšmès

Regresinis modelis

Pasikliautinasis intervalas $(p=0,99)$

Pasikliautinasis intervalas $(p=0,95)$

4 pav. Žemès paviršiaus judesiai 2005-1980 m. Jonavos Zarasu - Turmanto linijoje (tiesinis modelis)

Fig 4. Earth surface movements (2005-1980) in line Jonava Zarasai - Turmantas (linear model)

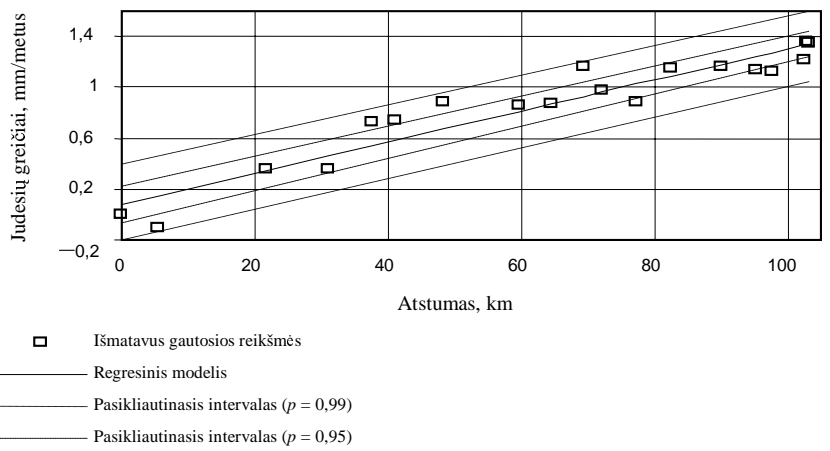

5 pav. Žemès paviršiaus judesiai $1970-1948$ m. Vilniaus Jonavos linijoje (tiesinis modelis)

Fig 5. Earth surface movements (1970-1948) in line Vilnius Jonava (linear model)

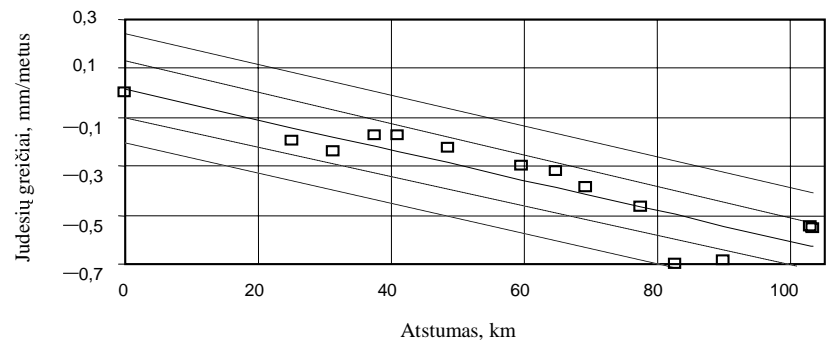

ㅁ̌mmatavus gautosios reikšmès

Regresinis modelis

Pasikliautinasis intervalas $(p=0,99)$

Pasikliautinasis intervalas $(p=0,95)$

6 pav. Žemès paviršiaus judesiai 1998-1970 m. Vilniaus Jonavos linijoje (tiesinis modelis)

Fig 6. Earth surface movements (1998-1970) in line Vilnius Jonava (linear model) 
1 lentelè. Vertikaliujų Žemės paviršiaus judesių greičiu kartotinių niveliacijų linijose regresiniai modeliai

Table 1. Regressive models of Earth surface vertical movements velocities in repeated levelling lines

\begin{tabular}{|c|c|c|c|c|c|c|}
\hline $\begin{array}{l}\text { Eil. } \\
\text { nr. }\end{array}$ & Laikotarpis, metai & Modelio tipas & Regresinis modelis & $R^{2} \%$ & $F$ & $\begin{array}{l}\left.F_{q\left(k_{1}, k_{2}\right)}\right) \\
q=0,05\end{array}$ \\
\hline \multicolumn{7}{|c|}{ Vilnius - Jonava } \\
\hline 1 & $1970-1971-1948$ & tiesinis & $V=0,0794306+0,0122182 \mathrm{~S}$ & 90,39 & 159,87 & 4,45 \\
\hline 2 & $1970-1971-1948$ & daugianaris & $\begin{array}{l}V=-0,0876459+0,0214171 \mathrm{~S}- \\
0,0000822368 \mathrm{~S}^{2}\end{array}$ & 94,01 & 125,59 & 3,63 \\
\hline 3 & $1998-1970-1971$ & tiesinis & $V=0,0145198-0,00619995 \mathrm{~S}$ & 82,95 & 58,39 & 4,75 \\
\hline 4 & $1998-1970-1971$ & daugianaris & $\begin{array}{l}V=0,00426268-0,00569516 \mathrm{~S}- \\
0,00000448455 \mathrm{~S}^{2}\end{array}$ & 82,99 & 26,85 & 3,98 \\
\hline \multicolumn{7}{|c|}{ Jonava - Zarasai - Turmantas } \\
\hline 5 & $1980-1935-1936$ & tiesinis & $V=-0,0506656-0,0082783 \mathrm{~S}$ & 73,78 & 81,62 & 4,19 \\
\hline 6 & $1980-1935-1936$ & daugianaris & $\begin{array}{l}V=-0,166305-0,00285029 \mathrm{~S}- \\
0,0000385096 \mathrm{~S}^{2}\end{array}$ & 76,69 & 46,05 & 3,30 \\
\hline 7 & $2005-1980$ & tiesinis & $V=0,17389+0,0241615 \mathrm{~S}$ & 92,17 & 282,58 & 4,26 \\
\hline 8 & $2005-1980$ & daugianaris & $\begin{array}{l}V=0,0506179+0,0282679 \mathrm{~S}- \\
0,0000242864 \mathrm{~S}^{2}\end{array}$ & 92,35 & 138,75 & 3,42 \\
\hline 9 & $2005-1935-1936$ & tiesinis & $V=0,111733+0,00455362 \mathrm{~S}$ & 74,66 & 35,36 & 4,75 \\
\hline 10 & $2005-1935-1936$ & daugianaris & $\begin{array}{l}V=-0,0404743+0,0105668 \mathrm{~S}- \\
0,0000401561 \mathrm{~S}^{2}\end{array}$ & 88,67 & 43,03 & 3,98 \\
\hline \multicolumn{7}{|c|}{ Turmantas - Vilnius } \\
\hline 11 & $1968-1948$ & tiesinis & $V=0,806167-0,034928 \mathrm{~S}$ & 91,6 & 262,88 & 4,26 \\
\hline 12 & $1968-1948$ & daugianaris & $\begin{array}{l}V=0,446864-0,0234874 \mathrm{~S}- \\
0,0000664643 \mathrm{~S}^{2}\end{array}$ & 92,3 & 138,53 & 3,42 \\
\hline 13 & $\begin{array}{l}2005-2006- \\
1985-1987\end{array}$ & tiesinis & $V=0,358233-0,0437929 \mathrm{~S}$ & 96,38 & 399,18 & 4,55 \\
\hline 14 & $\begin{array}{l}2005-2006- \\
1985-1987\end{array}$ & daugianaris & $V=0,457215-0,0480879 \mathrm{~S}+0,0000313674 \mathrm{~S}^{2}$ & 96,44 & 189,43 & 3,74 \\
\hline 15 & $1985-1987-1968$ & tiesinis & $V=-0,604423+0,0627611 \mathrm{~S}$ & 95,62 & 311,06 & 4,19 \\
\hline 16 & $1985-1987-1968$ & daugianaris & $\begin{array}{l}V=-0,719286+0,0670938 \mathrm{~S}- \\
0,0000286866 \mathrm{~S}^{2}\end{array}$ & 95,65 & 297,07 & 3,36 \\
\hline
\end{tabular}

Nagrinejjant tiesinius regresinius modelius, vertikaliujų Žemès plutos judesių intensyvumo ir krypties pokyčius einant laikui galima nustatyti iš greičių gradientų analizès. Gradientų ženklų pokyčiai reiškia Žemès plutos judesių krypties nagrinèjamoje linijoje pokyti, o greičiu gradientu absoliučiujų reikšmių pokyčiai judesių greičių pokyčius.

Tiesinių regresijos modeliu nagrinèjamojo poligono linijose gradientų analizès rezultatai pateikti 2 ir 3 lentelèse.

2 lentelèje judesių greičių gradientų reikšmès $\operatorname{grad}(v)$ ir gradientu standartiniai nuokrypiai $\sigma(\operatorname{grad} v)$, $t$ - statistikos ivverčiai ir jų patikimumo lygmuo. Iš 2 lentelès duomenų matyti, kad gradientų reikšmès statistiniu požiūriu nustatytos patikimai, nes visais nagrinetais atvejais $t$ - statistikos patikimumo lygmuo $q<0,01$, t. y. tikimybé, kad apskaičiuotos gradientu reikšmès apibūdina Žemès plutos vertikaliujų judesių savybes, $p \geq 0,99$.

Kad būtų galima nustatyti, ar vertikaliuju Žemès plutos judesių savybès keičiasi einant laikui, atlikta greičiu gradientų skirtumų analizè. Palyginti nevienodo judesiu pokyčio tose pačiose linijose laikotarpiais tarp kartotinių niveliacijų (žr. 1-6 pav.) regresijos modelių greičių gradientai. Apskaičiuoti gradientų skirtumai (18), standartiniai nuokrypiai (19), $t$ - statistika (20) ir $t-$ statistikos reikšme, esant patikimumo lygmeniui $q=0,05$.

Analizès rezultatai pateikti 3 lentelèje. Jais remiantis, su tikimybe, ne mažesne nei $p=0,95$, galima teigti, kad vertikaliuju Žemès plutos judesių greičių pobūdis (intensyvumas ir kryptis) einant laikui kinta, nes visais lygintais atvejais $t>t_{k, q}$.

2 lentelè. Vertikaliụų Žemès paviršiaus judesių greičių niveliacijų linijose tiesinių modelių gradientų analizė

Table 2. The analysis of the vertical Earth surface movements speed linear model gradients at the levelling lines

\begin{tabular}{|c|c|c|c|c|c|}
\hline Linija & Laiko tarpas, metai & $\operatorname{grad}(v)$ & $\sigma(\operatorname{grad} v)$ & Statistika $t$ & $\begin{array}{l}\text { Patikimumo lygmuo } \\
q\end{array}$ \\
\hline Vilnius - Jonava & 1970-1948 & 0,0122 & 0,0010 & 12,6 & $q<0,01$ \\
\hline Vilnius - Jonava & $1998-1970$ & $-0,0062$ & 0,0008 & 7,6 & $q<0,01$ \\
\hline Jonava - Zarasai - Turmantas & $1980-1935-1936$ & $-0,0082$ & 0,0009 & 9,0 & $q<0,01$ \\
\hline Jonava-Zarasai-Turmantas & $2006-1980$ & 0,0242 & 0,0014 & 16,8 & $q<0,01$ \\
\hline Jonava - Zarasai - Turmantas & $2005-2006-1935-1936$ & 0,0045 & 0,0008 & 5,9 & $q<0,01$ \\
\hline Turmantas - Vilnius & $1968-1948$ & $-0,0349$ & 0,0021 & 16,2 & $q<0,01$ \\
\hline Turmantas - Vilnius & $2006-1985-1987$ & $-0,0438$ & 0,0022 & 20,0 & $q<0,01$ \\
\hline Turmantas - Vilnius & $1985-1968$ & 0,0628 & 0,0025 & 24,7 & $q<0,01$ \\
\hline
\end{tabular}


3 lentelè. Regresinių modelių vertikaliụjų Žemès paviršiaus judesių greičių gradientų skirtumų analizė

Table 3. The differential analysis of the vertical earth surface movements speed regressive models

\begin{tabular}{|l|l|l|l|l|l|l|}
\hline \multicolumn{1}{|c|}{ Linija } & Laiko tarpas, metai & $\Delta \sigma$ & $\sigma(\Delta)$ & $t$ & $\begin{array}{l}t_{q, k} \\
(q=0,05)\end{array}$ & Pastabos \\
\hline Jonava - Vilnius & $1970-1948-1998-1970$ & 0,0184 & 0,0013 & 14,2 & 2,08 & $t>t_{q, k}$ \\
\hline Jonava - Turmantas & $2006-1980-2006-1935-1936$ & 0,0197 & 0,0016 & 12,3 & 2,06 & $t>t_{q, k}$ \\
\hline Jonava - Turmantas & $1980-1935-1936-2006-1980$ & 0,0334 & 0,0017 & 19,6 & 2,02 & $t>t_{q, k}$ \\
\hline Turmantas - Vilnius & $2006-1985-1987-1985-1987-1968$ & 0,1066 & 0,0033 & 32,3 & 2,02 & $t>t_{q, k}$ \\
\hline Turmantas - Vilnius & $1968-1948-2006-1985-1987$ & 0,0089 & 0,0031 & 2,9 & 2,03 & $t>t_{q, k}$ \\
\hline
\end{tabular}

Iš 1 ir 2 paveikslų matyti, kad Turmanto - Vilniaus linijoje 2006 - 1985-1987 m. bei 1985-1968 m. laikotarpiu vertikaliuju judesių kryptys yra priešingos, o judesių greičių kaitos amplitudè panaši. Panašus dèsningumas Jonavos - Zarasu - Turmanto linijoje 2006-1980 m. bei 1980 - 1935-1936 m. (3, 4 pav.) ir linijoje Vilnius - Jonava (5, 6 pav.) 1998-1970 ir 19701948 m. laiko tarpais.

\section{Išvados}

1. Dabartinių vertikaliujų Žemès plutos judesių greičių kaitos amplitudé Šiaurès Rytų Lietuvos regione siekia iki 4-6 mm per metus. Per pastarujuc 25 metu laikotarpi Zarasu - Turmanto teritorija Vilniaus Jonavos atžvilgiu kyla iki 4-6 mm per metus greičiu.

2. Su ne mažesne už $p=0,95$ tikimybe nustatyta, kad einant laikui keičiasi ne tik vertikaliujų Žemès plutos judesiu greičiai, bet ir kryptis.

3. Su tikimybe $p=0,95$ nustatyta, kad nagrinèjamame Šiaurès Rytu Lietuvos regione apibendrintasis vertikaliujų Žemès plutos greičiu modelis yra tiesinio pobūdžio. Tai gali būti paaiškinama didelio Žemès plutos bloko kaip vienalyčio kūno erdviniu judesiu.

4. Tokio intensyvumo judesius būtina îvertinti sudarant vertikaliuosius geodezinius tinklus.

\section{Literatūra}

1. ZAKAREVIČIUS, A. The research of the present vertical earth crust movements in Lithuania (Dabartiniu vertikaliu Žemès plutos judesių Lietuvos teritorijoje tyrimas). Vilnius: Technika, 1994. 276 p. (in Lithuanian).

2. ZAKAREVIČIUS, A. The research of the present geodynamic processes on the territory of Lithuania (Dabartinių geodinaminių procesu Lietuvos teritorijoje tyrimas). Vilnius: Technika, 2003. 195 p. (in Lithuanian).

3. SUVEIZDIS, P. Tectonic structure of Lithuania. Vilnius: Institute of Geology and Geography, 2003. 160 p. (in Lithuanian).

4. ILGINYTE, $\mathrm{V}$. The seismic active tectonic areas of Lithuania. Geologija, 1998, Nr. 23, Vilnius, p. 61-64 (in Lithuanian).

5. RANDJARV, J. Vertical movements of the Earth's crust in the Baltic Region. Reports of the Finish Geodetic institute, 93:2, Helsinki, 1993. 38 p.

6. ŽELNIN, G. O. The trustiness of the maps (schemes) of the earth crust movement speeds (based on the example Baltic territory maps). In The modern movements of Baltic territory. Tartu, 1975, p. 13-27 (in Russian).

7. ŠLIAUPA, S.; ZAKAREVIČIUS A.; STANIONIS, A. Strain and stress fields in the Ignalina NPP area from GPS data and thin-shell finite element modeling. Geologija, 2006, Vol 56, Vilnius, p. 27-35 (in Lithuanian).
8. ZAKAREVIČIUS, A. The rezults of investigation of vertical movements of the Earth Crust in Ignalina Nuclear pover plont geodynamic polygon. Geodezija ir kartografija, 1997, Nr 1 (25), p. 78-85 (in Lithuanian).

9. ZAKAREVIČIUS, A.; TURIJ, N. The partial removal of measuring bias at the Borisov-Vileika geodynamical polygon vertical earth crust movements research. The news of universities, Geodesy and air photo, 1988, No 5, p. 57-64 (in Russian).

10. MARTIŠIUS, S. A.; KĖDAITIS, V. Statistics, part II. The conclusions and solutions of statistics. Vilnius: VU publishing, 2004. 341 p. (in Lithuanian).

11. KAZAKEVIČIUS, S. V. The first land levelling nets in Lithuania. Earth Planning and Melioration, 1998, No 3 (95), p. 72-82 (in Lithuanian).

12. KAZAKEVIČIUS, S. V. The renewal and organisation of the main levelling net of Lithuania 1970-1987 m. Earth Planning and Melioration, 2000, No 1 (101), p. 95-106 (in Lithuanian).

13. The creation of the first class nation vertical geodetic net of Lithuania. The report of the scientific work (part VI). VGTU, The faculty of environmental engineering, Institute of geodesy, 2005 (in Lithuanian).

14. The technical report of the first class lines Riga - Elgava Liepaja - Elgava - Baranovich levelling. Object 3 - 327 North - West geodetic aero geodetic company GUGK, Leningrad, 1949. 107 p. (in Russian).

15. The creation of the first class nation vertical geodetic net of Lithuania. The report of the scientific work. VGTU, The faculty of environmental engineering, Institute of geodesy 2006 (in Lithuanian).

16. The research and development of the gravimetric and height base of Lithuania. The report of the scientific work, VGTU The faculty of environmental engineering, Institute of geodesy. 1998 (in Lithuanian).

Algimantas ZAKAREVIČIUS. Professor, Doctor Habil. Dept of Geodesy and Cadastre, Vilnius Gediminas Technical University, Sauletekio al. 11, LT-10223 Vilnius, Lithuania, $\mathrm{Ph}+3705274$ 4703, e-mail: Algimantas.Zakarevicius@ap.vgtu.lt.

A graduate of Kaunas Polytechnic Institute (now Kaunas University of Technology), geodetic engineer, 1965. Doctor's degree at Vilnius University, 1973. Dr Habil degree at VGTU, 2000. Member of the Geodetic Commission of Estonia, Latvia and Lithuania. Research training at Geodetic Institute of Norwegian Mapping Authority, 1994. Author of over 140 publications and 3 monographs.

Research interests: investigations of the recent geodynamic processes, formation of geodetic networks.

Asta ANIKÉNIENÉ. Doctoral student. Dept of Geodesy and Cadastre, Vilnius Gediminas Technical University, Sauletekio al. 11, LT-10223 Vilnius, Lithuania, Ph +370 5274 4703, e-mail:asta@ap.vgtu.lt

Master of Science, 2000. Research interests: investigation of geodynamic processes, GIS, investigations of deformations. 